\title{
Shi'i Identity and Nationalism in Indonesia's Reformasi
}

\author{
Z. Zulkifli \\ Syarif Hidayatullah State Islamic University, Jakarta, Indonesia \\ zulkifli@uinjkt.ac.id
}

\begin{abstract}
Indonesia is home to the largest Muslim population in the world in which the Shi'i minority exists amidst the overwhelming Sunni majority. Indonesia's reformasi has paved the way for the rise of identity politics and, about Sunni-Shi'i relation, the upsurge of anti-Shi' $i$ activism. Among anti-Shi' $i$

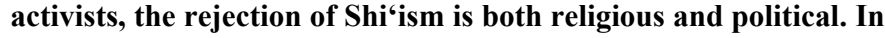
addition to its falsity and being source of social conflict, Shi'ism has been accused as a threat to the nation and state. Shi'ism as an ideology is seen contrary and never comfortable with the state ideology of Pancasila, the 1945 Constitution, and the Unitary State of the Republic of Indonesia (NKRI). So, is Shi'ism compatible with Indonesian nationalism? In a specific way, what is the Shi' $i$ attitude toward Pancasila, the 1945 Constitution, and NKRI? What are socio-political contexts and factors contributing the transformation of Shi'i identity? This paper is in general aimed at examining whether Shi'ism is compatible with Indonesian nationalism. It systematically explains socio-political context and factors contributing to the transformation of Shi ${ }^{6} \mathrm{i}$ identity and analyzes the Shi'i attitude toward Indonesian nationalism. Based on available written sources, the paper finds that Indonesia's reformation with its democratization, the moderate attitude of Islamic organizations, and the organizational stage in the internal Shi' $i$ community are factors contributing to the transformation of Shi'i identity from resistance to project identity. The paper also uncovers that in accordance with the project identity Shi'ism is compatible with Indonesian nationalism and the Shi'is have a positive attitude toward Pancasila, the 1945 Constitution, and NKRI.
\end{abstract}

Keywords - Shi' i identity, nationalism, Indonesia, reformation

\section{INTRODUCTION}

Sectarian identity has dominated studies of Sunni-Shi' $i$ relations in the Muslim world, including Indonesia where the growing Shi'i minority exists amidst the overwhelming Sunni majority. Indonesia's reformasi since 1998 has paved the way for the rise of identity politics and, about Sunni-Shi'i relation, the upsurge of anti-Shi'i activism. Among anti-Shi' $i$ activists, the rejection of Shi'ism is not only seen as a religious issue but also framed from its political aspect. In addition to its falsity and being source of social conflict, Shi'ism has been accused as a threat to the nation and state. Shi'ism as an ideology is seen contrary and never comfortable with the state ideology of Pancasila, the 1945 Constitution, and the Unitary State of the Republic of Indonesia (NKRI). Furthermore, Shi' is' loyalty is framed only to Iran. The general purpose of this paper is to examine whether Shi'ism is compatible with nationalism. Systematically, it will explain socio-political context and factors contributing to the transformation of Shi' $i$ identity and analyze the Shi'i attitude toward Indonesian nationalism. The study is focused on two mass Shi' $i$ organizations, namely IJABI (Ikatan Jamaah Ahlulbait Indonesia, All-Indonesian Assembly of Ahl al-Bayt
Associations) and ABI (Ahlulbait Indonesia, Ahl al-Bayt of Indonesia) using data collected from written sources on both organizations and those produced by them.

\section{TRANSFORMATION OF SHI'I IDENTITY}

To start an analysis of Shi'i sectarian identity, Jenkins' simple definition of identity is applicable. "Identity is our understanding of who we are and who other people are, and, reciprocally, other people's understanding of themselves and of others (which includes us). It is a very practical matter, synthesizing relationships of similarity and difference" [1]. The Shi'is adhere to a minority denomination of Islam which "venerates the twelve Imam who succeeded the Prophet Muhammad and adopts a specific set of practices as a consequence of its belief systems" [2]. This sets them apart from the Sunni majority even though they both share numerous similarities regarding fundamentals of Islam. But synthesizing Sunni-Shi'i relations includes similarity and difference not only in religious aspect but also social, political and cultural aspects. Therefore, as Jenkins points out, identification is not always fixed and may be negotiated [1].

The Shi' $\mathrm{i}$ identity is socially and historically constructed. It is also influenced by several interrelated factors: religious and political, domestic and international. Since Indonesian Shi'is are minority amidst the largest Sunni majority, the Shi' $i$ identity is a product of interaction to Sunnis who also form the majority of the world's Muslim population. Social and political contexts also contribute to the construction process. In short, the construction of Shi' $i$ identity is always contextual.

Referring to Castells's classification of identity into legitimizing identity, resistance identity, and project identity [3], in Indonesia there has been the transformation of Shi' $i$ identity from resistance identity to project identity. During the New Order period (1966-1998) the Shi'i identity in Indonesia may be categorized as resistance identity which is "generated by those actors that are in positions/conditions devalued and/or stigmatized by the logic of domination, thus building trenches of resistance and survival on the basis of principles different from, or opposed to, those permeating the institutions of society" [3]. In the identity building, the Indonesian Shi 'is expressed "the exclusion of the excluders by the excluded" and the outcome of resistance identity was the formation of commune or communities [3]. In other words, the Shi' $i$ community was the community of resistance.

The formation of Shi'i community as the community of resistance came into existence under the New Order 
authoritarian regime under President Suharto with the depoliticization of Islam in 1980s. The de-politicization of Islam enforced Pancasila as the sole foundation of the state, providing no room for free expression of different political ideas, particularly political Islam. The regime had a strong ability to use Pancasila and instruments of state political control to affirm its commitment to development and order, placing Islam as the main threat to the national unity and the ideology of Pancasila. The formation of Shi' $i$ community is to a certain extent a response to and a rejection of this depoliticization of Islam by the state. To those interested in Shi'ism during the formative years of Shi'i community, the leadership principle in Shi 'ism, namely imamate, is seen as an alternative to the de-politicization of Islam, rejecting the implementation of Pancasila as the sole basis.

The formation of Shi' $i$ communities in Indonesia is a continuing process that may change in different times and social and political context because identity is understood as "not only a historical and social construction, but also a part of a continual process of transformation and change" [4]. "Shi'ism is dynamic, wherever it exists Shi'ism always colours and is coloured by its surrounding culture" [5]. Therefore, Shi ${ }^{\circ} i$ identity in Indonesia is dynamic.

Indonesia's reformasi with its democratization process has paved the way for the transformation of Shi' $i$ identity. The emergence of the 1998 reform movement that emphasized the democratic life of the state and society provided an opportunity for freedom of expression. Indonesia has witnessed an increase in the number and intensity of socioreligious movements, civil societies, and political parties. In this regard, the Shi' $i$ community took advantage from this new socio-political development and saw it as an opportunity to openly express and redefine its Shi' $\mathrm{i}$ identity which, before the reformation, it took care to hide. Two national mass Shi ${ }^{\circ} i$ organizations were established during the reformation: first, IJABI was established on 1 July 2000 during Abdurrahman Wahid's presidency (1999-2001). Centred in Bandung, IJABI has been led by prominent Shi'i intellectual and leader Dr. Jalaluddin Rakhmat, currently a member of parliament for Indonesia Democratic Struggle Party (PDIP). IJABI has 200 branches in 32 provinces throughout the entire country except for Jambi and West Papua [6]. Second, representing Sayyids (those claiming to be descendants of the Prophet Muhammad), Qum alumni, and those reluctant to join IJABI, ABI was set up on 27 July 2010. It is centered in Jakarta and led by Dr. Umar Shahab as the chairman of Consultative Council and Hasan Daliel Alaydrus as the head of Executive Board. ABI has 87 branches in 23 provinces in Indonesia [6]. Through these two organizations, the meaning and expression of Shi ${ }^{\circ} \mathrm{i}$ identity are channeled. The establishment of the two Shi ${ }^{\circ} \mathrm{i}$ organizations means that the Shi' is in Indonesia have gained the official national recognition.

Asides from the macro socio-political context of Indonesian state and society, the institutional support of Islamic organizations, i.e., NU (Nahdlatul Ulama) and Muhamadiyah with their moderate attitude toward Shi'ism is another factor contributing to the transformation of Shi' $\mathrm{i}$ identity. The moderate attitude is then followed by dialogue and cooperation between the two organizations and Shi' $\mathrm{i}$ organizations, IJABI and ABI. The recognition from the two big Islamic organizations completes the state's official recognition regarding the Shi' $\mathrm{i}$ identity, its practice and activities. It should be noted that recognition is central to identity formation [7]. "Our identity is partly shaped by recognition or its absence" [8].

In addition to the macro-political context and institutional support of Islamic organizations, the internal factor of the Shi' $\mathrm{i}$ community is necessary condition for the transformation of Shi'i identity into project identity "when social actors...build a new identity that redefines their position in society and, by so doing, transformation of overall social structure" [3]. The development of Shi'i community in Indonesia is marked with the change from individual phase to institutional phase and finally to the organizational stage. The organizational stage may symbolize the maturity of the community in taking into consideration of its position and role in facing threats, challenges, constraints as well as opportunities. The setting up of Shi'i organizations indicates the awareness and responsibility of the Shi' is in the establishment of modern civilization, the implementation of justice, and the manifestation of harmonious life that also become the responsibility of all Indonesian citizens. The founding of $\mathrm{ABI}$ as a mass organization demonstrates "a very strong national determination to stand at the forefront in facing the nation's challenge...[and] an authentication of legal consciousness of Indonesian Shi'i community to generate its social role in the framework of nationally recognized laws and regulations" [5]. This willingness illustrates the project identity of the Shi' $i$ community to participate in the national development, Muslim progress, and human civilization through the organizational channels.

\section{NATIONALISM}

There is no doubt about the positive attitude of the Shi' is in Indonesia toward Indonesian nationalism. "The Shi' is in Indonesia position themselves as an integral part of this nation and are proud of being part of this big nation" [5]. They are not only proud of being citizens of Indonesian state and members of Indonesian society but also loyal to the state ideology of Pancasila, the 1945 Constitution, and the Unitary State of the Republic of Indonesia (NKRI). This is evident in IJABI's Pancasila Declaration on 1 June 2017 in that it always attempts to play an active role in an endeavor to keep upright the Unitary State of the Republic of Indonesia based on Pancasila and the 1945 Constitution:

With Pancasila, we invite all elements of the nation to jointly maintain and care for the Unitary State of the Republic of Indonesia (NKRI) and fight against any attempt to replace the foundation and pillar of our nation and state. Let every flower sprouts in the homeland called Indonesia. Indeed, among great gifts 
from this country is the introduction to us plurality, diversity, and ideology to maintain the diversity within unity: Bhinneka Tunggal Ika [9].

As an integral part of the nation, the Shi'is see that they have the equal rights and obligations, like other Indonesian citizens, to maintain the national integration, namely to take care of the state ideology of Pancasila, the 1945 Constitution, NKRI, and Bhinneka Tunggal Ika. Furthermore, because loving the nation is obligatory, they feel obliged to participate in the development and progress of Indonesian nation and society. As mentioned previously, the founding of IJABI and $\mathrm{ABI}$ is meant to optimize the Shi' is' contributions.

Closely related to the attitude of the Shi'is toward nationalism, it is clear that they reject all forms of separatist movement. ABI... "reemphasizes the attitude and principle of Islamic organization Ahlulbait of Indonesia that recognize and uphold Pancasila and the 1945 Constitution as the basis of Unitary State of the Republic of Indonesia. Therefore, ABI views that Pancasila and NKRI are final and should not be contested" [10]." It is said that ABI is prepared for actively motivating all its members and other segments of Indonesia society to express loyalty to the state ideology, Pancasila, and participating in establishing that all regulations in the country are not contrary to the 1945 Constitution. Loyal attitude toward the state's Constitution sets in motion readiness of the members and institution of ABI to protect the Unitary State of the Republic of Indonesia as the official form of the state [5]. Like ABI, IJABI rejects any separatist movements through its Declaration of Unity which states: "We are determined to be at the forefront preserving the unity of the Unitary State of the Republic of Indonesia from the destruction of those who want to tear it down openly or secretly [11]."

The Shi'is in Indonesia certainly reject the accusation of their being loyal to Iran even though they do not deny the influence of Iran in Shi'ism in Indonesia that has created suspicion of having a political tendency like Shi'ism in Iran. They argue that the characteristics of the two countries differ. Unlike Iran, Indonesia is one of the most heterogenous countries in the world. Regarding ethnicity, for instance, Iran tends to have one ethnic group namely Persian whilst Indonesia has numerous ethnic groups with their language and culture. "Certainly the Shi'is in Indonesia are more elastic in appreciating the differences and deeply upholding the country where they are born rather than Iran as a country far away" [5]. Their rejection of being loyal to Iran is combined with that they see the unique characteristic of Indonesian Shi'ism because of the dynamic nature of Shi'ism. "The Shi'is in Indonesia are neither Arabian Shi'is, nor Iranian Shi'is, nor any other Shi'is, except Indonesian Shi'is who have Indonesian character and ethics" [5] because Shi'ism develops by the characteristics of its community.

The accusation that the Shi' $\mathrm{i}$ community in Indonesia would found an Islamic state ala Iran when it gains big followers is without proof. That Iran became the Islamic Republic was a product of referendum, not by force, which was conducted to gain acceptability and legality of the government system. Additionally, despite the fact that the Shi'is form a majority in Iraq and they take a most important position in the government, Iraq does not directly become an Islamic state like Iran. The Iranian experience with its Islamic Republic is unique to Iran and therefore cannot be implemented in other countries, let alone Indonesia which is sharply different from Iran.

With regard to the system of emulation, it is true that the Shi'is follow a marja' (source of emulation) from other countries, most being Ayatollah Ali Khamenei of Iran, but it is only consultative regarding disputed matters in the form of the fatwa. A fatwa is never dealt with theological doctrine and undisputed matters. "As Indonesian citizens, loyalty to the jurist consult (not Rahbar) — currently most believe to be held by Ali Khamenei-is limited only in fiqh matters or ritual of obedience, certainly not political loyalty" [5]. The Shi'is' belief in wilayat al-faqih (governance of the jurist) is not to be understood as their political loyalty to Iran in spite of the fact that the jurist is Iranian. It is true that he is also Rahbar meaning the highest authority in the Iran's constitution that abides all Iranian citizens. The implication of the concept of wilayat al-faqih even emphasizes the territorial context of Indonesian state and nation for Indonesian Shi'is. "Wilayat alfaqih is meaningful when the Shi'i community becomes a part of the nation itself. As faith and good deed must be balanced in aspects of our life, a Shi'i's faith becomes perfect by the obedience of oneself to the state and nation where he lives" [5]. Thus, the system of emulation in Shi'ism does not reduce but even affirms, the Shi'is' political loyalty to the Indonesian state and nation.

\section{CONCLUSION}

Indonesia's reformasi with its democratization process, institutional support of Islamic organizations with their moderate attitude, and the internal development of the Shi' $i$ community with the establishment of the mass organization have contributed to the transformation of Shi'i identity from resistance identity to project identity. With the project identity, the Shi' is in Indonesia through the mass organizations have a positive attitude toward Indonesian nationalism in that they are loyal to and prepared to maintain Pancasila, the 1945 Constitution, NKRI, and Bhinneka Tungga Ika, rejecting any separatist movements and Iranian style of an Islamic state. In accordance with the dynamic nature of Shi'ism, the Shi'is in Indonesia have developed their unique characteristic of Indonesian Shi'ism. 


\section{References}

[1] Jenkins, Richard 2008 Social Identity. London and New York: Routledge.

[2] Zulkifli 2013 The Struggle of the Shi is in Indonesia. Canberra: ANU E Press.

[3] Castells, Manuel 1997 The Power of Identity. Oxford: Blackwell Publishers.

[4] Giroux, Henry A. 2005 Border Crossings: Cultural Workers and Politics of Education. 2nd Edition. New York and London: Routledge.

[5] Tim ABI 2014 Syiah Menurut Syiah. Jakarta: DPP Ahlulbait Indonesia.

[6] IPAC 2016 The Anti-Shi'a Movement in Indonesia. IPAC Report no. 27.
[7] Zulkifli 2014 "Education, Identity, and Recognition: The Shi'i Islamic Education in Indonesia" Studia Islamika: Indonesian Journal for Islamic Studies 21, 1: 77-108.

[8] Taylor, Charles 1994 "The Politics of Recognition" Amy Gutman (ed) Multiculturalism: Explaining the Politics of Recognition. Princeton, NJ: Priceton University Press, 25-73.

[9] www.ijabi.or.id/komitmen/deklarasi-pancasila accessed 22 August 2017.

[10] www.ahlulbaitindonesia.or.id/berita/ahlul-bait-indonesiamenolak-separatisme-di-indonesia accessed 22 August 2017.

[11] www.ijabi.or.id/komitmen/deklarasi-persatuan-ijabi accessed 30 August 2017. 